\title{
OPEN SURGICAL VS. MINIMALLY INVASIVE TREATMENT OF THORACOLUMBAR AO FRACTURES TYPE A AND B1 IN A REFERENCE HOSPITAL
}

\author{
TRATAMENTO CIRÚRGICO ABERTO VS. MINIMAMENTE INVASIVO DE FRATURAS \\ TORACOLOMBARES AO TIPO A E B1 EM UM HOSPITAL DE REFERÉNCIA
}

\author{
TRATAMIENTO QUIRÚRGICO ABIERTO VS. MÍNIMAMENTE INVASIVO DE LAS FRACTURAS \\ TORACOLUMBARES AO TIPO A Y B1 EN UN HOSPITAL DE REFERENCIA
}

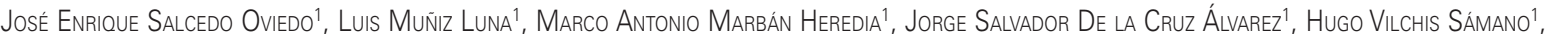 \\ Juvenal Ordaz Vega ${ }^{1}$, Yadira Bahena Salgado ${ }^{1}$, Mario Alonso Cienega Valerio ${ }^{1}$, Emilio Barbarin ${ }^{1}$
}

1. Instituto Mexicano del Seguro Social, Advanced Specialty Medical Unit Lomas Verdes, Spine Surgery Unit, Naucalpan de Juárez, Estado de México.

\begin{abstract}
Objective: The thoracolumbar spine trauma represents $30 \%$ of spinal diseases. To compare the minimally invasive technique with the open technique in lumbar fractures. Method: A prospective, cross-sectional, comparative observational study, which evaluated the following variables: surgery time, length of hospital stay, transoperative bleeding, postoperative pain, analyzed by SPSS software using Student's $t$ test with statistical significance of $p \geq 0.05$, with 24 patients with single-level thoracolumbar fractures, randomly treated with percutaneous pedicle screws and by open technique with a transpedicular system. Results: The surgery time was 90 minutes for the minimally invasive technique and 60 minutes for the open technique, the bleeding was on average $50 \mathrm{~cm}^{3} \mathrm{vs} .400 \mathrm{~cm}^{3}$. The mean visual analogue scale for pain at 24 hours of surgery was 5 for the minimally invasive group vs. 8 for the open group. The number of fluoroscopic projections of pedicle screws was 220 in the minimally invasive technique vs. 100 in the traditional technique. Quantified bleeding was minimal for percutaneous access vs. $340 \mathrm{~cm}^{3}$ for the traditional system. The hospital discharge for the minimally invasive group was at 24 hours and at 72 hours for those treated with open surgery. Conclusions: It is a technique that requires longer surgical time, with reports of less bleeding, less postoperative pain and less time for hospital discharge, reasons why it is supposed to be a procedure that requires a learning curve, statistical significance with respect to bleeding, visual analogue scale for pain and showed no significant difference in the variables of surgical time.
\end{abstract}

Keywords: Spinal fractures; Surgical procedures, operative; Minimally invasive surgical procedures.

RESUMO

Objetivo: O trauma da coluna toracolombar representa 30\% das doenças de coluna. Comparar a técnica minimamente invasiva com a técnica aberta em fraturas lombares. Método: Estudo prospectivo, transversal, comparativo e observacional, que avaliou as seguintes variáveis: tempo de cirurgia, tempo de internação, sangramento transoperatório, dor pós-cirúrgica, analisadas pelo software SPSS usando o teste $t$ de Student com significância estatística de $p \geq 0,05$, com 24 pacientes com fraturas toracolombares em um só nível, tratados randomicamente com parafusos pediculares por via percutânea e por técnica aberta com sistema transpedicular. Resultados: O tempo de cirurgia foi 90 minutos para a técnica minimamente invasiva e 60 minutos para a técnica aberta, o sangramento foi em média $50 \mathrm{~cm}^{3}$ vs. $400 \mathrm{~cm}^{3}$. A escala visual analógica média para dor às 24 horas da cirurgia foi de 5 para o grupo minimamente invasivo vs. 8 para o grupo aberto. O número de projeções fluoroscópicas de parafusos pediculares foi de 220 na técnica minimamente invasiva vs. 100 na técnica tradicional. O sangramento quantificado foi mínimo para o acesso percutâneo vs. $340 \mathrm{~cm}^{3}$ para o sistema tradicional. A alta hospitalar para o grupo minimamente invasivo foi às 24 horas e às 72 horas para os tratados com cirurgia aberta. Conclusões: É uma técnica que exige maior tempo cirúrgico, com relatos de menor sangramento, menos dor pós-operatória e tempo menor para alta hospitalar, motivos pelos quais se supõe que é um procedimento que requer uma curva de aprendizagem, significância estatística com relação ao sangramento, escala visual analógica para dor e não mostrou diferença significante nas variáveis de tempo cirúrgico.

Descritores: Fraturas da coluna vertebral; Procedimentos cirúrgicos operatórios; Procedimentos cirúrgicos minimamente invasivos.

\section{RESUMEN}

Objetivo: El trauma de la columna toracolumbar representa un 30\% de las enfermedades de la columna. Comparar la técnica mínimamente invasiva contra la técnica abierta en fracturas lumbares. Método: Estudio prospectivo, transversal, comparativo y observacional, que evaluó las siguientes variables: tiempo quirúrgico, tiempo de internación, sangrado transquirúrgico, dolor posquirúrgico, analizados por el software SPSS utilizando la prueba t de Student para significación estadística $p \geq 0,05$, con 24 pacientes con fracturas toracolumbares de un nivel, tratados de forma aleatoria mediante tornillos pediculares por vía percutánea vs. técnica abierta con sistema transpedicular. Resultados: El tiempo quirúrgico fue de 90 minutos para la técnica mínimamente invasiva y de 60 para la técnica abierta; el sangrado fue

Study conducted at the Instituto Mexicano del Seguro Social, Advanced Specialty Medical Unit Lomas Verdes, Spine Surgerey Unit, Naucalpan de Juárez, Estado de México.

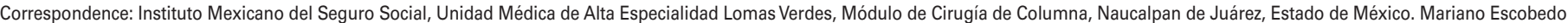
número 221, col. El Huerto Cuautitlán, Mexico, 54807. drsalcedo1969@yahoo.com 
en un promedio de $50 \mathrm{~cm}^{3}$ vs. $400 \mathrm{~cm}^{3}$. La escala visual analógica promedio del dolor a las 24 horas del tratamiento quirúrgico fue de 5 para el grupo mínimamente invasivo vs. 8 para el grupo abierto. El número de proyecciones fluoroscópicas de tornillos pediculares fue de 220 en la técnica mínimamente invasiva vs. 100 en la técnica tradicional. El sangrado cuantificado fue mínimo para el acceso percutáneo vs. $340 \mathrm{~cm}^{3}$ para el sistema tradicional. El egreso hospitalario para el grupo mínimamente invasivo fue a las 24 horas, y a las 72 horas para Ios tratados con cirugía abierta. Conclusiones: Es una técnica que requiere mayor tiempo quirúrgico, con reportes de menor sangrado, menor dolor postoperatorio y un tiempo de egreso hospitalario menor, por lo que se asume que es un procedimiento que requiere una curva de aprendizaje, significación estadística en cuanto al sangrado, escala visual analógica del dolor y no mostró diferencia significativa en las variables de tiempo quirúrgico.

Descriptores: Fracturas de la columna vertebral; Procedimientos quirúrgicos operativos; Procedimientos quirúrgicos mínimamente invasivos.

\section{INTRODUCTION}

Dorsal and lumbar vertebrae are frequently the sites of fractures produced by high-energy accidents that occur in the economically active population. ${ }^{1}$

They have an incidence of from 15 to $29 \%$ among males, with $52 \%$ involving the thoracolumbar junction (T11 to L1) and 32\% involving $\mathrm{L} 2$ to $\mathrm{S} 1$. The primary injury mechanism, in $45 \%$ of patients, is being run over, followed by falling from heights in 35\%.

However, geriatric patients also suffer thoracolumbar fractures, but they generally result from low-energy accidents (osteoporosis).

Thirty percent of polytraumatized patients suffer persistent pain from hidden vertebral fractures following high-energy trauma. ${ }^{1,2,3}$

In the evaluation of spinal injuries, $50 \%$ go unnoticed and $25 \%$ can develop neurological deterioration. ${ }^{4}$

Compression fractures reach in incidence of almost $60 \%$, many of them treated conservatively. ${ }^{5}$

Surgical treatment is indicated when there is vertebral collapse greater than $50 \%$ and kyphosis greater than $20^{\circ}$, as this situation can lead to mechanical instability, with a risk of progression of the vertebral collapse, sagittal imbalance, neurological damage, etc. ${ }^{6}$

The use of pedicle screws to achieve stability, as well as to restrict movements in all planes, has increased in recent years and is safe and effective for this type of pathology. ${ }^{7}$

The usual techniques for osteosynthesis with pedicle screws require extensive tissue dissection associated with greater blood loss, increased postoperative pain, longer hospitalizations, and higher costs. $^{7}$

The use of percutaneous or minimally invasive techniques offers an option that meets the requirements for stabilization of the fractures, improving postoperative pain, trans- and postsurgical bleeding, and time in the hospital. ${ }^{8}$

Thoracolumbar fractures are a frequently occurring pathology, with a high demand for economic, hospital, hematological, and physical resources, and a complication rate of between 5 and $20 \%$. With the advent of minimally invasive techniques to treat these fractures, these factors are reduced, one of the reasons for which the realization of this study is justified.

\section{Problem approach}

\section{Research question}

- Is there less bleeding with the minimally invasive technique as compared to the open technique?

- Is surgical time shorter with the minimally invasive technique in comparison to the open technique?

- Is there less pain in the immediate postoperative period with the minimally invasive technique as compared to the open technique according to the numeric analog pain scale?

- Do patients who undergo minimally invasive surgery spend fewer days in the hospital than those who are operated on using the open technique?

- Is the number of transoperative radiographic exposures (fluoroscope) lower with minimally invasive techniques as compared to the open technique?
This study compares the minimally invasive technique with the open technique in type A and B1 lumbar fractures treated in the spine unit of a high-concentration trauma center of the Instituto Mexicano del Seguro Social (HTOLV).

Its objectives are: to show that there is less bleeding with the minimally invasive technique as compared to the open technique; to determine whether surgical time is shorter with the minimally invasive technique than with the open technique; to determine whether there is less pain in the immediate postoperative period with the minimally invasive technique as compared to the open technique; to quantify whether the number of hospital days is less for patients undergoing the minimally invasive technique than for those operated on using the open technique; and to count the number of transoperative radiographic exposures (fluoroscope) with minimally invasive techniques as compared to the open technique.

\section{METHODS}

This observational, cross-sectional, comparative, and prospective study was conducted at the Instituto Mexicano del Seguro Social, in the Spine Unit of the Hospital de Traumatología y Ortopedia Lomas Verdes, from 1 October 2014 to 1 October 2015.

It was approved by the Institutional Review Board of the Hospital Traumatología y Ortopedia Lomas Verdes

Study group: Patients covered by the Instituto Mexicano del Seguro Social with type A (A2, A3, A4) and B1 lumbar fractures who were admitted for emergencies to the Hospital de Traumatología y Ortopedia Lomas Verdes and later hospitalized in the Spine Unit.

\section{Inclusion criteria}

Male patients between 18 and 60 years of age, who have type $A$ (A2, A3, and A4) and B1 type fractures. Beneficiaries of the Instituto Mexicano del Seguro Social who have suffered a high-energy accident and present a type A or B1 lumbar fracture (pincer, incomplete burst, complete burst).

Surgical fracture according to the Vaccaro criteria. Surgical treatment on average within the first 7 days (time range 4-10 days) following the occurrence of the fracture.)

\section{Exclusion criteria}

Patients with fractures at other levels of the musculoskeletal system. Patients with cranioencephalic trauma, uncontrolled diabetics who cannot undergo surgery in a range greater than 10 days.

Twenty-four patients, 12 in the group managed using the minimally invasive technique and 12 in the group managed with the open technique.

Independent variables: Fixation of the fracture treated with the open or minimally invasive technique. One level above and one below the fractured vertebra.

Conceptual and operational definition of the variables.

Dependent variables: Surgical time, quantification of bleeding, visual analog scale (VAS) for pain, days in the hospital, number of radiographic exposures (fluoroscope).

Having previously documented and classified the type of lumbar fracture, the surgical treatment was randomly proposed for each 
patient. The objectives of the study, the scope, the benefits, and the possible complications were explained via informed consent.

At the end of the surgical procedure, the duration of the surgery and the bleeding were quantified with the assistance of the attending anesthesiologist. The number of radiographic exposures was documented. The next day, the numeric analog scale was used to document pain intensity. The general conditions of the patient were evaluated for discharge 24 hours following the surgical procedure. If not possible, they were reevaluated for discharge every 24 hours. The Student's t test was used for statistical analysis and a significant difference of $p<0.05$ was used.

\section{RESULTS}

There were 24 male patients between 25 and 60 years of age, divided into 2 groups with average bleeding of 50cc and 600cc, respectively (Figure 1).

Patients who underwent minimally invasive surgery were discharged after 24 hours and those who underwent open surgery after 72 hours (Figure 2).

The surgical time was 90 minutes for the minimally invasive technique and 60 minutes for the open technique (Figure 3).

The number of radiographic projections was 220 versus 100, respectively (Figure 4), that showed burst-type fracture of the first lumbar vertebra, with a Vaccaro score of more than 5 points and without neurological lesion.

The visual analog scale for pain score was 5 for the minimally invasive group and 8 for the open surgery group.

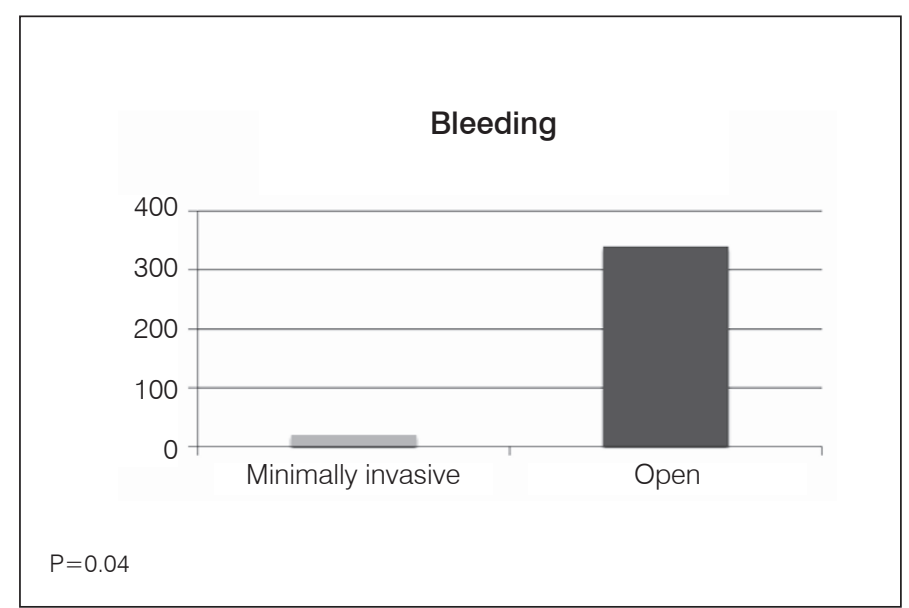

Figure 1. Quantity of bleeding in both techniques.

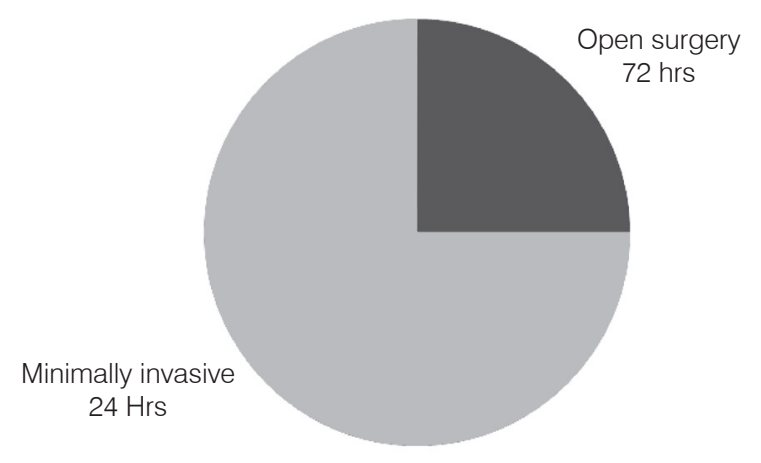

$\mathrm{P}=0.02$ minimally invasive discharged after $24 \mathrm{hrs}$

Figure 2. Number of days in the hospital.

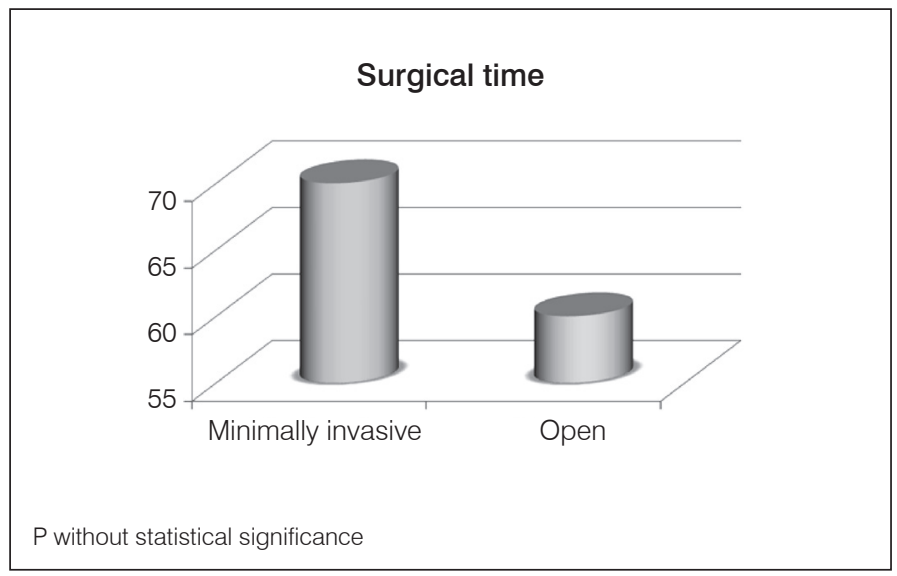

Figure 3. Quantity of bleeding in both surgicals techniques.

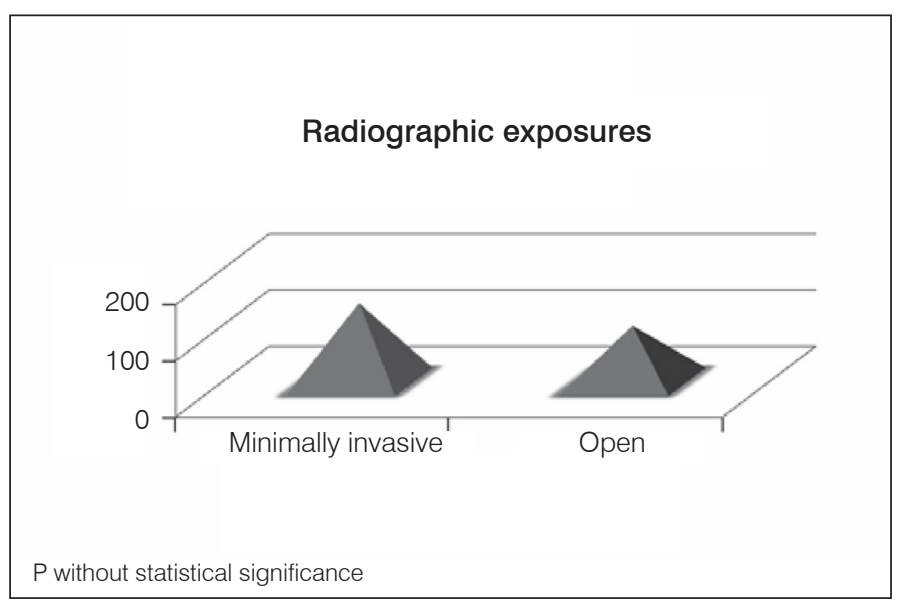

Figure 4. Number of radiographic exposures in both surgical techniques.

\section{DISCUSSION}

Minimally invasive surgery is a new technique in our hospital that with experience acquired over time will reduce surgical time significantly. The patients who underwent the minimally invasive technique evolved with less pain in the perioperative period and did not require blood transfusions. There is greater exposure to radiation for the placement of the percutaneous screws and more technical and economic resources are needed for the use of minimally invasive systems, costing up to $40 \%$ more than the open technique. Radiographic exposure and surgical time for the procedures also were gradually reduced by $55 \%$ and $42 \%$, respectively, for the last patients managed via the minimally invasive technique. This reduction implies better mastery of the surgical technique. The minimally invasive procedure is increasingly used in the orthopedic and traumatic treatment of spine surgery.

\section{CONCLUSION}

According to the study results, the minimally invasive technique has several advantages over the open technique. Surgical time is a variable that increased because of its technical difficulty and recent introduction to our hospital and represents a long-term risk to the safety of the surgeon. However, more studies of radiation doses are required to be able to evaluate their effect on the surgical personnel. The statistical analysis shows that the variables with significant differences were the quantity of bleeding, less postoperative pain, and the time to discharge from the hospital, all significantly lower for the minimally invasive technique, which translates into an effective technique for treatment of thoracolumbar fractures at a single 
level. A reduction in surgical time and in the number of fluoroscopic projections was observed as compared to the first patients treated with the minimally invasive technique, because it is a procedure that requires a learning curve. In addition, from the postoperative results, we conclude that it is a safe surgery, although we cannot rule out the possibility of extremely destructive complications due to the characteristics of the surgery.

However, we should not consider that all these injuries should be treated using this surgical technique. Treatment should always be guided by a focus on the intrinsic characteristics of the fracture, the classification, the technical resources, and the skill of the surgeon.

The global trend in healing fractures is moving towards minimally invasive techniques.

All authors declare no potential conflict of interest related to this article.

CONTRIBUTION OF THE AUTHORS: Each of the authors participated actively in the elaboration of the protocol and the surgery of the patients. As well as in the analysis of the results and in the final elaboration of the manuscript. JESO, LML, MAMH, Main contributors in the elaboration of the manuscript. JESO, MACV, LML, MAMH and JOV, participated in the surgeries of the patients. JESO, JSCA, HVS and YBS were given the task of following the postoperative of the patients and control in the external consultation. JESO, EBR and ELVE took on the task of analyzing the results as well as the statistical methodology. JESO and ELVE collected the bibliography. All participated developed the conclusions and discussion of them as well such as the elaboration of graphs and relevant points of the study.

\section{REFERENCES}

1. Escribá IU, Escribá IR, Sancho FG. Fracturas por estallido toracolumbares: Pasado, presente y futuro. Rev Españ Cir Ost. 2006;42(277):122-30.

2. Camilo J, Vives A, Esguerra M, La Rotta G, Orjuela M, Gil C. Entendiendo la clasificación de las fracturas toracolumbares por el sistema "AO". Rev Colomb Radiol.2014; 25(2):394-54.

3. Bazán PL, Borrill AE, Torres PU, Cosentino JS, Games MH. Clasificación de las fracturas toracolumbares: comparación entre las clasificaciones de $\mathrm{AO}$ y Vaccaro. Coluna/Columna. 2010;9(2):165-170.

4. Cortés V, Ordaz V, Salazar M, Martínez G, Gómez L. Diagnóstico y principios del tratamiento quirúrgico de las fracturas de vertebras toraco-lumbares secundarias a traumatismo en el adulto. IMSS 673-13 [acesso em: 24 de março 2016] Disponível em: http:// cenetec-difusion.com/gpc-sns/?p=1784
5. Tejeda Martín. Clasificación de las fracturas toracolumbares. Ortho-tips. 2010;6(2):114-21.

6. Del Pilar ZA. Resultados instrumentación transpedicular en fracturas traumáticas torácicas y lumbares inestables Hospital Occidente de Kennedy 2003-2012 [tesis]. Bogotá Colombia: Universidad Nacional de Colombia; 2012.

7. Neira J Stefano C. Pautas para la evaluación de las lesiones de columna vertebral en pacientes traumatizados [acesso em: 24 de março]. Rev Arg Med Cir Traum. Disponível em: http://www.medynet.com/usuarios/jraguilar/columna\%201\%20y\%20 $2 \% 20 \% 20$ parte.pdf

8. Matta J, Arrieta V, González M, Jaimes L. Abordaje selectivo antero lateral para manejo de fracturas de la región columbar (T12, L1, L2). Rev Med. 2013;21(1):54-62. 